\title{
William Dawson (1734-1815): Improver and Philosopher
}

\author{
TONY VOSS
}

In the heritage literature of Kelso and the Scottish Borders, the names of William Dawson 'the improver', and Thomas Pringle (1789-1834), 'poet and philanthropist', are often mentioned with honour. For a short while, when Dawson was approaching retirement and Pringle was still a schoolboy, they were neighbours, but the overall careers of the improver and the man who came to be known as 'the father of South African English poetry' could hardly have been more different.

Thomas Pringle was born in the year of the French Revolution, but his early education and up-bringing in rural Roxburghshire in the late eighteenth and early nineteenth centuries sprang from old Scottish traditional roots, on which Pringle continued to develop throughout his life. The Kelso Grammar School, to which Pringle was sent at the age of 13 in 1802, had been serving what George Elder Davie called 'The Democratic Intellect' since its foundation in the seventeenth century: the syllabus in which Pringle was schooled there may not have changed very much during that time. On the other hand, the Scottish Enlightenment had significant effects even in Kelso, and certainly when he got to Edinburgh University in 1802, Pringle seems to have been exposed to at least the afterglow of that intellectual movement. However, on the basis of what direct evidence we have, Pringle's individual initiatives as a student seem to have been evangelical in social direction, and romantic in literary emphasis. After he left the University, his undertakings in journalism and belles lettres, though unexceptionable and even honourable, were not able to exploit the radical moment of his time.

By 1819, Pringle faced a double crisis: both the rural and the urban dimensions of his culture were threatened. The evangelical values he had brought from the country had not been proof against the ambitious scepticism of the Edinburgh of the Napoleonic War and its immediate aftermath. In that year, Pringle had returned to his archival work at Register House. In the same year the fragile economic foundations of Pringle's rural heritage were exposed:

A series of bad harvests, and the low prices which came after the long French war, had driven the tenant of Blakelaw [Pringle's father, Robert], like many of his neighbours, to the verge of ruin (Leishman: 50).

It is not surprising that the Pringles were vulnerable to the blandishments of the Colonial Office and its 'scheme of colonising the waste lands at the Cape' (ibid.) Thomas Pringle led the 'Scottish Party' to settle on the Eastern Cape frontier in 1820. His lateral descendants are still there, and 


\section{TONY VOSS}

some of the Scottish names he gave the landscape are still on the map of South Africa. But Pringle left South Africa in 1826, and settled in London as secretary of the Anti-Slavery Society. He died in 1834, shortly after the passing of the act of Parliament which abolished slavery in the British Empire: a liberation which he had been instrumental in achieving. The African experience which Pringle had embarked on as a result of his Scottish setbacks proved, in the end, central to his total achievement.

The work and personality of William Dawson, who lived his whole life in the Scottish lowlands, but for a few years in England during his early manhood, make an illuminating comparison with Pringle's case. Pringle too, was a farmer; in settling in South Africa he had to adapt from the mixed farming of his Borders youth to traditional African cattle pasturage on the Eastern Cape frontier. Pringle is now mainly remembered in South Africa as a writer and liberal activist. While Dawson is mainly remembered as an agriculturist, he deserves also to be remembered as a writer. William Dawson was born in February 1734, on Harpertoun, a farm in the parish of Ednam, Berwickshire, of which his father was the tenant. At the age of sixteen Dawson was sent to England to learn new farming methods. It may be that his travels were sponsored by his father's landlord; it was not unknown for promising sons of tenant farmers to be advanced by noble landowners in this way. (Burnet: 1) According to one nineteenth-century source 'after a liberal education' Dawson ‘was sent by his relations into England' (Forsyth 1841: II,74). For four years Dawson trained with John Ball, the agent of the Duke of Leeds, on the estate near Sheffield, then spent another year at Lord Fitzwalter's estate in Essex. Before he returned to Harpertoun in 1753, Dawson had met both Robert Bakewell and Arthur Young 'his contemporaries in age and outlook' (Burnet: 1), and he had observed Jethro Tull's experiments with drilling and turnip husbandry. Dawson is described as having spent his years in England

labouring with his own hands under respectable farmers, to whose care he had been committed in consequence of recommendations obtained from Scotland to persons of rank, under whom their farms were held (Forsyth 1841 II:74).

A strong sense emerges of Dawson's robust character and the complex of social obligations within which he worked. Certainly, when Dawson took over his father's lease of Harpertoun at $£ 83.13 .4 \mathrm{~d}$. per annum, he was ready to put theory and training into practice on his own account.

Like many tenant farmers of his time, Dawson faced daunting problems on Harpertoun. The impoverished and waterlogged soil was beset by perennial weeds. There was no reliable winter feed for cattle. Farm workers were ill-educated, fatalistic and resistant to change. It was difficult to raise the credit necessary to implement innovation. In the end the soil of Harpertoun proved too thin for turnips, but Dawson enclosed the whole farm, drained the soil and concentrated on 
improving it in other ways. After a few years he had developed the farm to the extent that, for the remaining seven years of its lease, it could be let at $£ 331.6 .8 \mathrm{~d}$. per annum. ${ }^{1}$

In 1759, Dawson took a lease of Frogden, about eight miles south east of Harpertoun in the parish of Linton, across the county border in Roxburghshire, from Wauchope of Niddrie, who was also the landlord of the Pringles on the immediately neighbouring farm of Blaik Law, two miles to the north. Frogden was run down: unenclosed, undrained, without modern tillage. With the support of the landowner, Dawson enclosed the whole farm. In the absence of stones, he used broom to build faggot drains, which proved to have a life of over thirty years. At his own expense, he limed the farm and then cropped it on a four-year rotation. When the soil seemed to be exhausted, Dawson left it to pasture for several years, sown with clover, and folded sheep on the pasture. Heavy crops followed.

Turnip cultivation required skilled ploughing. Dawson had become a master ploughman in England and set about teaching his Scottish farm labourers himself. His best pupil, James MacDougall, went on to train many others, until Frogden-trained ploughmen were in demand north and south of the border. By 1762, Dawson was able to begin turnip drilling on a large scale, an innovation which soon proved its worth. By 1778, when Andrew Wight, author of The Present State of Husbandry in Scotland (1778-1784), visited Frogden, he found the land clear of weeds, extensive drill husbandry of turnips under way, and convenient stalls, stables and sheds of the tenant's own design in place (II: 355-358). Farm implements had been invented or modified by Dawson's ingenuity, labourers were well housed, well fed and well paid. New crops, such as red oats, and novel feeds, such as 'yams' (coarse potatoes) for horses, had been introduced. The farming was profitable, and credit was readily available.

As his success continued, Dawson leased two more farms, Morebattle Tofts and Grubbets, both of which he improved, and finally bought Graden, an extensive estate adjoining Frogden. Before the turn of the eighteenth century, Dawson had founded a school 'for the benefit of those in the north-eastern part of the parish' of Linton (Mackie and Robson: 8), where Thomas Pringle may have been a pupil. The school lay midway between Blaik Law and Graden. Dawson was a member of the Morebattle library, and, more than likely, of the Union Agricultural Society of Kelso. In 1784 he was a subscriber (for two copies) of Captain John Marjoribanks' Trifles in Verse, published in Kelso.

As was the case with Thomas Pringle, class was a powerful determinant of William Dawson's career. A tenant farmer like Dawson held his land, by the payment of 'ferm', of a subject rather than of the crown; until he was able to buy, to own Graden, Dawson would not have had the right to cast a vote for the knight of the shire. He thus suffered the political exclusion of his neighbour tenant farmers like the Pringles; yet Dawson's advanced practice of agriculture and

\footnotetext{
${ }^{1}$ Wight's Present State of Husbandry has Dawson making 'repeated journeys to England' after taking over Harpertoun (Wight II 1778: 341).
} 


\section{TONY VOSS}

husbandry isolated him from them and aligned him with the landowning 'gentleman farmers' of his time.

Dawson's achievement was generally acknowledged in his own lifetime, in both the popular imagination, and by word of mouth among at least the Borders farming community, and also in the prestigious national and county surveys of agriculture of the late $18^{\text {th }}$ century (Douglas, Ure, Wight). Andrew Wight's 1778 summary is characteristic:

His [Dawson's] reputation is high, and he is imitated by every farmer of activity, gentleman or tenant. Not a farm in the neighbourhood is to be seen about him, but what wears the face of improvement (Wight: II 1778, 34342).

David Ure, in 1794, seemed more concerned with the gentlemen of Roxburgh, than the tenants, and mentions Dawson only briefly for his introduction of turnip-drilling into the county (34). Robert Douglas, in his national account of 1798, acknowledges the many aspects of Dawson's achievement: his improvement of such implements as the harrow (p.51), the introduction of red oats (85), turnip-drilling (84-5, fn.), drains lined with broom in the absence of sufficient stone (131), and the use of marl and lime as manure (135).

Dawson is sometimes identified as a 'farmer' to distinguish him from gentlemen, a distinction which might parallel that between land-owner and tenant. The social mobility that generates the relationship emerges from the two definitions of 'gentleman-farmer' in the $O E D$ : both 'a country gentleman engaged in farming, usually on his own estate' - Lord Kames, for example and 'a farmer who holds a better social position than the generality of his class' - Dawson. A paradox, perhaps, as Lord Kames, who is named here as one of Dawson's predecessors, seems to have anticipated when he published The Gentleman Farmer: an Attempt to Improve Agriculture by Subjecting it to the Test of Rational Principles in 1776. Whereas 'In former times, hunting was the only business of a gentleman...How delightful the change', Kames wrote ( xix) 'from the hunter to the farmer'. While the social hierarchy seems to have been in flux, it is interesting that in 1798, in his General View of the agriculture in the counties of Roxburgh and Selkirk, Robert Douglas reported:

It may not be improper to mention that since the account of Roxburghshie went to press, some alteration has taken place in the state of property there, by which a larger share of it now belongs to peers' (376) .

Dawson's anomalous social (and historical) position is well illustrated by Robert Forsyth, whose The Beauties of Scotland (1805) offers the most eloquent, just and sympathetic account of Dawson's achievement. Dawson was not the first Scot, but the first Scot of his class, to introduce certain agricultural improvements. 
He was the first Scottish farmer who introduced the cultivation of turnip in the open field. Previous to this date, Cockburn of Ormiston...had introduced them in East Lothian; and about the same period, they were tried by Lord Kaimes in Berwickshire: but practical farmers paid little attention to the enterprises of these or other gentlemen, who attempted to introduce novelties into agriculture. It was impossible for them to calculate correctly the expence attending such pretended improvements, or the profit derived from them. The farmers knew that, though a rich man might throw away some money in forming a garden, adorning his pleasure-ground, or introducing a new crop into some of his fields, he could suffer little by the expence, though the adventure should prove totally unprofitable; but they wisely considered themselves in a very different situation. They had rents to pay, and families to support, by the produce of their industry; and they would have accounted themselves guilty of unpardonable rashness, if they had deserted the plan by which they knew these objects could be accomplished, for the purpose of imitating wealthy men in their costly experiments and projects. But when Mr. Dawson, on the lands of which he became tenant, and for which he paid what was accounted a full rent, began to engage in this new career, the matter was considered in a different light. He was at first regarded as a rash young man who had imported a set of foreign notions, which in all probability would speedily bring him to ruin, and no practical farmer hesitated to predict this termination to his enterprises. At the same time it was evident, that if he should succeed in his operations, his neighbours must speedily change their sentiments. Thus, upon the success or failure of this gentleman in his projects as a farmer did the fate, for many years to come, of the agriculture of Scotland depend (745).

In this last sentence Dawson is both 'gentleman' and 'farmer, but generally he is a 'Scottish farmer', one of the 'practical farmers', payers of rent, as against the 'wealthy proprietors of land' (76). Lacking the protection and creditworthiness of ownership -- of property - most of Dawson's fellow-tenant farmers could hardly afford to risk radical change. They were themselves in a sense bound to a labour-intensive and family-based system. Perhaps the Pringles were among the neighbouring tenant farmers who responded cautiously to the innovations of 'Dawson, the Improver', reluctant to follow him in 'imitating wealthy men in their costly experiments and projects'. The social barriers between farmers and hinds seem to have been as impermeable as those between 'practical farmers' and 'men of fortune'. Dawson was also an expert and innovative ploughman and sought to pass on his expertise . In Forsyth's account, Dawson finds 


\section{TONY VOSS}

that emulation only exists among equals; and that, as practical farmers disregarded the fine crops of turnips, and even of grain, raised by wealthy proprietors of land, so ordinary ploughmen did not feel themselves disgraced by their inferiority to a young farmer who had received a literary and afterwards an English education (76).

Only when they see that Dawson is becoming 'a rich man' (77) do his neighbours seek to emulate him. Only when he has trained, after two years, one 'expert ploughman' are other 'servants' and 'workmen' ready to learn. ${ }^{2}$

When he was nearly seventy, and while Thomas Pringle was still attending the 'Latin' school in Kelso, William Dawson retired to settle in Edinburgh. His elder son took over Morebattle Tofts and his younger son took over Frogden. ${ }^{3}$ The Edinburgh and Leith Post Office Directory first lists 'William Dawson, Esq.' in 1804 (covering the period July 1804 to July 1805), and as resident at ' 19 Catherine Street, head of Leith Walk', a good enough address in an area of the city developed in the late 1770s. The Directory of 1805 drops William Dawson's 'Esq.' but finds him at the same address. After two years at No. 15, Catherine Street, Dawson moved to 2, Heriot Row East for a year, then to 2, Heriot Row West, before settling in about 1811 at 21 Heriot Row, where he lived until his death in 1815. (Pringle never enjoyed so good an address in Edinburgh.) Although he had retired from 'practical' farming, William Dawson clearly continued his interest in agricultural advancement and liberal activism. In 1810 he subscribed \$5.0.0 to the fund for Andrew Meikle 'who invented and brought to perfection, that valuable and important Implement to Husbandmen, -- the Thrashing-Machine'. Dawson had been the first to propose the fund, some years before, 'but thrashing-machines not being then generally introduced, it was deemed proper to delay carrying it into execution till a more convenient season' (Anon. 1810: 465).

In retirement Dawson published, in the form of a letter to the editor of The Farmer's Magazine, what seems to be his only account of his own agricultural experimentation. 'Of the difference in the effect of dung upon different soils' details Dawson's transformation of both Harpertoun and Grubbitts into rich pastureland. The style seems characteristically self-effacing, as

\footnotetext{
${ }^{2}$ Forsyth's tribute to Dawson was plagiarised through the nineteenth century (Anon., 1835, 1836, 1840, and Percy 1823). The Chambers account is particularly distasteful in its condescension to Dawson's fellowfarmers and to the workers and servants.

${ }^{3}$ Dawson and his wife Elizabeth were also the parents of six daughters, one of whom, Janet (1767-1828) was married to the Rev. David Brown of Crailing, the author of 'A Tour in Scotland in 1802'. Another daughter, Euphemia (1772-1828), was the wife of the Rev. William MacRitchie, of Cluny, author of 'From Perth to Carlisle in 1795', which gives a glimpse of Dawson: 'Drank tea with Mrs Douglas (sister of Mr Dawson of Graden). She introduced us to her niece Mrs. Jeffrey [Agnes, née Dawson (1762-1832)] and her husband, from Ross-shire, who are in their way to see her father and friends, with whom I passed some happy days last summer' (MacRitchie: 111).
} 
when Dawson writes that 'accidental circumstances' (Dawson 1812: 69) had directed his attention to the effects of lime as manure on different soils, but the writer's patience, precision and courage emerge nonetheless.

Perhaps more interesting and important today are two works of political economy which occupied Dawson in his last decade. In 1805 he published Thoughts on Public Trusts, an extended argument for constitutional constraints on the trust reposed in rulers. Dawson's 'Introduction' quotes Hume on the contrast between an 'absolute' and a 'republican and free' government, but argues that many absurdities have been committed in the name of republican governments, only the Roman Republic having maintained 'for above 600 years... with any degree of steadiness...a continued succession of rulers, of talents and public spirit' (vii).

The tract goes on to develop this contrast between 'the integrity and patriotism of the rulers in antient Rome, and the rapacity of the rulers in modern France' (x), Dawson's idealisation of the Roman Republic finds the key to its success in the fact that all public offices were elective and in such constraints against oligarchy as the 'Agrarian Law of Licinius' (45), which 'took from the patricians their usurped rights' and 'prohibited any Roman from possessing above 500 acres' (46). Dawson defends this measure against an anticipated charge of 'levelling' (47) in a way that assumes that society is always and everywhere stratified. The ruin of the Roman constitution came after the murder of the Gracchi, who had tried to renew and enforce the Agrarian Law, with the descent into despotism consequent on the 'practice of determining laws and elections by force' (64).

Dawson gives his understanding of the lesson of the history of France since the revolution in various ways:

absolute power, even in the hands of plain men, even though formerly patriots, produces as fatal consequences as when it is in the hands of a king or a set of nobles (78).

The corruption of absolute power is exacerbated by the conditions of war, and 'Absolute power is not the less pernicious, that it emanates from the Society' (114: title of Chapter IV). Dawson's conclusion is that 'Equality of rights [is] as advantageous to the highest ranks as to the lowest' (120: title of Chapter VII). Not Agrarian Laws but 'despots...are...from pride, and for their own security, the most determined and effectual levellers' (146). Dawson thus seems concerned to maintain a balance between equality of opportunity and due recognition of individual merit and talent.

Dawson's second structural contrast, designed to illustrate the proper reposal of trust in public officers, is drawn between 'The Constitution of the American States' and 'the Constitution of the American Bank' (147). The latter is like the constitution of the Roman Republic in that the directors are able to exercise 'such powers only as...judged necessary for executing the business of the company' (153); their powers are limited to management, but 'the legislative power, and 


\section{TONY VOSS}

the disposal of office remain with the proprietors' (154). Dawson's business orientation has a distinctly 'new conservative' ring.

But the concluding chapter of Thoughts on Public Trusts marks it as very much of its time, in a tradition of utopias of the British Enlightenment, a tradition whose terms had been fundamentally altered by the French revolution (Claeys: xxvi). Dawson's utopia is offered as 'A Sketch of a Constitution for an Extensive, Populous Country upon the Roman model' (157: title of Chapter IX). Dawson's 'ideal' constitution (158) imagines a high degree of devolution of power to provinces (+/- 1,500,000 souls), in which few inhabitants live more than 40 miles (1 day's journey) from the 'provincial meeting-place'. 40 is both the voting and the office-holding age. The elective process moves pyramidally from wards (each of 4,000 persons, hence about 300 voters). Dawson argues that his constitution 'proceeds, like that of Rome, upon the common principle of business; appointing no agents but as they become necessary, giving no unnecessary power to those that are appointed, and preserving a full control over them' (184-5). But one can sense Dawson's optimistic revision of the society of the late eighteenth-century Scottish Borders in his claim that

men who are selected by their neighbours, as the properest persons for judging and determining their differences, are much more likely to be qualified for that trust, and also for electing senators and other great officers, than men who are selected by certain measures of property (189/90).

And 'Dawson the Improver', perhaps remembering his suspicious neighbour tenant farmers, can be heard in such a passage as this:

How many thousand useful bridges might be built, pieces of roads made, land inclosed, and commons divided, if the people of the provinces and districts, who only are concerned, had legislative power, but which cannot be done when it costs a large sum to procure the authority of the national legislature in each case (200).

In the last year of his life William Dawson published another tract, An Inquiry into the Causes of the General Poverty and Dependence of Mankind; including a Full Investigation of the Corn Laws. This seems at first to be an answer to Adam Smith's An Inquiry into the Nature and Causes of the Wealth of Nations, and harks back to the stadial model of universal history which was a recurring motif of the Scottish Enlightenment, an idea which helped shape Pringle's understanding of his South African experience. Dawson begins with a Chapter 'Of the causes of the equality of men as to rank in nations of hunters; and of the dependent situation to which the majority of the people are reduced in the shepherd state' (1). While 'common sense' suggests, despite 'the natural aversion of man to labour', that 'the shepherd state' would have been 'the original state of societies in all...countries' such as North America, there seem to have been no domestic animals there at the time of first European settlement. Yet individuals are more 
independent and self-reliant in 'nations of hunters and fishers' (3); hence the paradox that the order which offers 'the reliability of sheep and cows' also requires 'masters and servants' and hence 'fawning...lower classes' and 'high ranks...more assuming and insolent to the low'(4).

In Section I of Chapter Two Dawson deals with 'the effects of the appropriation of land', arguing that increase of population and the concentration of private property in land in the hands of a few individuals must force farmers to 'give a greater part of the produce for liberty to occupy land' and 'labourers a greater part of their time for food' (11). Section Two recalls Smith's critique of the law of primogeniture: in Dawson's words, it has 'a powerful tendency to lessen the numbers of mankind' and 'to make them slaves' (11). This is surely Dawson the tenant farmer speaking, observing the effects of the Napoleonic wars which had enriched both farmers and landlords.

In these circumstances, when there is no prospect of relief from emigration, men will submit to any inconvenience or harshness of treatment; they will even sell themselves and children for slaves, rather than be banished from their native place, and run the risk of perishing for want of food and clothes, and a house to shelter them (12).

Pringle was one who did seek 'relief from emigration'. Perhaps Dawson is thinking of the 'bondager' system (which Pringle must also have remembered in slave-owning South Africa), and that there was a negative side to the general progress of the age of improvement: 'A hired hind was much less 'his own man' than his father had been. The unmarried worker often lived in conditions little better than the hovels of two hundred years before' (Mackie and Robson: 11). Dawson argues that the law of primogeniture was a major factor in the tendency 'to reduce all...to an abject dependence and wretchedness, except the owners of land...' (18).

Dawson's two tracts, then, are very much documents of their time: in their frustration at the corruption and poverty persisting in apparently sophisticated and productive societies, and in their residual Enlightenment utopian vision. But it is not as a political economist that Dawson is remembered, though he deserves to be. The heritage industry of the Borders (e.g Forsyth) and academic histories of farming (e.g. Ernlé) remember him as an 'improver'. One history of Kelso acknowledges that 'As an author, Mr Dawson was original and ingenious. His style, however is rude and unpolished' (Haig: 313). In 1845, Professor J.R. M'Culloch published The Literature of Political Economy: a Classified Catalogue, which does not mention Dawson or either of his tracts, but in 1837 M'Culloch had found space for a mention of Dawson the improver in his two-volume A Statistical Account of the British Empire, an early Victorian and imperial version of the enlightenment 'Statistical Accounts' of Scotland. M'Culloch, then, recognised Dawson as a practical improver, but not as a thinker, a contributor to political economy. Marx was to dismiss the 'pretentious cretinism' (416) and the 'miserable prattle of Sycophant MacCulloch' (679). 
The anonymous 'Memoir of the late William Dawson, Esq., of Graden', which appeared in The Farmer's Magazine of Monday $8^{\text {th }}$ May 1815, rises to a flourish which aligns Dawson with other heroes of the Borders:

...the same remarkable district, the scene of so many bloody conflicts, -which trained to war and tumult the turbulent heroes of Border story - the Douglases, and Homes and Scotts, -- can boast, in our own times, a host of names more beneficently illustrious. The houses of Home and Elliott have produced Lord Kames, Lord Heathfield, and Lord Minto. Of humbler origin, Leyden and Park, with all the indefatigable intrepidity of their ancestors, have persevered, and (unhappily for the world) have perished in the prosecution of far nobler enterprises, -- and the parish of Ednam, which gave birth to the poet of the Seasons, also produced the Father of Scottish Husbandry - William Dawson... (169).

In a strangely ironic turn, William Dawson and Thomas Pringle are brought together in what follows to conclude the 'Memoir': 12 octosyllabic couplets evoking the beauty, the history and the productivity of the Scottish Borders. These lines, with some amendments, would form part of the anonymous 'Epistle to Mr. R.S.***' which James Hogg was to include in his collection of parodies, The Poetic Mirror, or, The Living Bards of Britain, when it was first published in London and Edinburgh the next year. When Dawson's 'Memoir' appeared, the editor of The Farmer's Magazine was James Cleghorn (also from a Borders farming family). The author of the 'Epistle...' was Thomas Pringle and when the poet himself first published the poem under the title The Autumnal Excursion, or, Scenes in Teviotdale and under his own name in 1819, he dated it 1811. In 1817 Pringle and Cleghorn were joint editors of the first issue of Blackwood's Magazine (Vigne 2012: 31).

\section{ACKNOWLEDGEMENTS}

I am grateful to the late Professor Alexander Fenton, who encouraged my interest in Dawson and gave me the generous hospitality of the School of Scottish Studies while I was on sabbatical leave in Edinburgh. I should also like to thank Mrs. Marguerita Burnet, who kindly gave me a copy of her then unpublished biographical essay on Dawson. My thanks also to Marc di Sotto, to the State Library of New South Wales, to the National Library of Scotland and to the editor and readers of Scottish Studies. As a student of South African literature it was natural for me to be interested in the life and work of Thomas Pringle. In the course of research in Edinburgh I learned about Dawson, whose work, as both an improver and a writer, seems to me to justify further scholarly interest. 


\section{SOURCES}

ANON.

$1810 \quad$ 'List of Subscribers for Rewarding Mr Meikle', The Farmer's

Magazine, December, Vol. XI, 465-476.

1815 'Memoir of the late William Dawson, Esq., of Graden', The Farmer's

Magazine, May, Vol. XVI 163-169.

1835 'Example of Industry and Perseverance', in Young Gentleman's

Library..., Philadelphia: 49-52.

1836 'Dawson the Improver'. Chambers' Edinburgh Journal, No.216. March 19: 60-61.

1840 'The Father of Scottish Agriculture'. In The Book of Notable Things. Glasgow: 172-174.

BROWN, REV. DAVID.

1902 'A Tour in Scotland in 1802'. The Scottish Antiquary, or, Northern Notes and Queries, Vol. 17, No. 65: 15-25.

BURNET, MARGUERITA.

n.d. (1992?) 'William Dawson of Frogden and Graden, 1734-1815: "Father of the Agriculture of the South of Scotland"'. Unpublished typescript draft.

CLAEYS, GREGORY.

$1994 \quad$ Utopias of the British Enlightenment. Cambridge.

DAWSON, WILLIAM.

$1805 \quad$ Thoughts on Public Trusts. Edinburgh.

1812

'Of the difference in the effect of dung upon different soils...' The Farmer's Magazine, March, Vol. XIII: 69-73.

1814 An Inquiry into the Causes of the General Poverty and Dependence of Mankind, including a Full Investigation of the Corn Laws, Edinburgh, London.

DOUGLAS, ROBERT.

1798 General View of the agriculture in the counties of Roxburgh and Selkirk: with observations on the means of their improvement, drawn up for the consideration of the Board of Agriculture and Internal Improvement...

ERNLÉ, LORD . Edinburgh.

1961

English Farming, Past and Present [1919]. 6th. ed., intro. G.E. Fussell and C.A. MacGregor. London. 


\section{TONY VOSS}

FORSYTH, R.

1841

The Beauties of Scotland [1805-1809], 5 vols. London (Vol. II, 1808:.74-77).

HAIG, JAMES.

1825

A Topographical and Historical Account of the Town of Kelso.

Edinburgh, London.

KAMES, HENRY HOME, LORD

1776 The Gentleman Farmer Being an Attempt to Improve Agriculture by

Subjecting it to the Test of Rational Principles. Edinburgh: Creech;/

London.

LEISHMAN, J.F.

$1937 \quad$ Linton Leaves. Edinburgh and London

MACKIE, A.O. AND M.J.H. ROBSON.

n.d. The Parish of Linton: a Short Account of the Parish.

MACRITCHIE, WILLIAM. 'From Perth to Carlisle in 1795'. The Scottish Antiquary, or $1896 \quad$ Northern Notes and Queries, Vol.10, No. 39: 109-114

MARX, KARL.

1974 Capital, Volume One (1887). Ed. Frederick Engels. London.

M'CULLOCH, J.R.

1837

1845

$O E D$

1974 The Compact Edition of the Oxford English Dictionary (1971), 2 vols. New York.

PERCY, SHOLTO AND REUBEN.

1823 'Father of Scottish Agriculture', in the Percy Anecdotes, Original and

Select, 20 vols. London: Vol. 18: 68-72.

[PRINGLE, THOMAS].

1816

'Epistle to R.S.****' in James Hogg ed., The Poetic Mirror, or The Living Bards of Britain. London.

URE, DAVID.

1794

VIGNE, RANDOLPH.

2012

Thomas Pringle: South African Pioneer, Poet and Abolitionist. Woodbridge, Suffolk. 
WALDIE, J.S.L.

1951

'William Dawson, 1734-1815'. Agricultural Progress Vol. 26.

WIGHT, ANDREW.

1778-1784 Present state of husbandry in Scotland extracted from reports made to the Commissioners of the Annexed Estates, and published by their

authority, 4 vols., Edinburgh, London. Vols. 1 and 2: 1778, vols. 3 and 4, 1784.

1784 'A Young Soldier' [Captain John Marjoribanks]

Trifles in Verse. Kelso. 